\title{
26. ISOTOPIC AND TRACE ELEMENT COMPOSITION OF BASALTS FROM SITES 556-559 AND 561-564: CONSTRAINTS ON SOME PROCESSES AFFECTING THEIR COMPOSITION ${ }^{1}$
}

\author{
G. A. Jenner, Max-Planck-Institut fur Chemie, \\ J. Hertogen, Katholieke Universiteit, \\ and \\ Th. Sachtleben and H.-U. Schmincke, Ruhruniversität ${ }^{2}$
}

\begin{abstract}
$\mathrm{Sr}$ and $\mathrm{Nd}$ isotopic composition of 23 basalts from Sites 556-559 and $561-564$. are reported. The ${ }^{87} \mathrm{Sr} /{ }^{86} \mathrm{Sr}$ ratios in fresh glasses and leached whole rocks range from 0.7025 to 0.7034 and are negatively correlated with the initial ${ }^{143} \mathrm{Nd} /$ ${ }^{144} \mathrm{Nd}$ compositions, which range from 0.51315 to 0.51289 . The $\mathrm{Sr}$ and $\mathrm{Nd}$ isotopic compositions (in glasses or leached samples) lie within the fields of mid-ocean ridge basalts (MORB) and ocean island basalts (OIB) from the Azores on the $\mathrm{Nd}-\mathrm{Sr}$ mantle array/fan plot.

In general, there is a correlation between the trace element characteristics and the ${ }^{143} \mathrm{Nd} /{ }^{144} \mathrm{Nd}$ composition (i.e., samples with $\mathrm{Hf} / \mathrm{Ta}>7$ and $(\mathrm{Ce} / \mathrm{Sm})_{\mathrm{N}}<1$ [normal-MORB] have initial ${ }^{143} \mathrm{Nd} /{ }^{144} \mathrm{Nd}>0.51307$, whereas samples with $\mathrm{Hf} / \mathrm{Ta}<7$ and $(\mathrm{Ce} / \mathrm{Sm})_{\mathrm{N}}>1$ (enriched-MORB) have initial ${ }^{143} \mathrm{Nd} /{ }^{144} \mathrm{Nd}$ compositions $<0.51300$ ). A significant deviation from this general rule is found in Hole 558, where the N-MORB can have, within experimental limits, identical isotopic compositions to those found in associated E-MORB.

The plume-depleted asthenosphere mixing hypothesis of Schilling (1975), White and Schilling (1978) and Schilling et al. (1977) provides a framework within which the present data can be evaluated. Given the distribution and possible origins of the chemical and isotopic heterogeneity observed in Leg 82 basalts, and some other basalts in the area, it would appear that the Schilling et al. model is not entirely satisfactory. In particular, it can be shown that trace element data may incorrectly estimate the plume component and more localized mantle heterogeneity (both chemical and isotopic) may be important.
\end{abstract}

\section{INTRODUCTION}

The origin of chemical and isotopic heterogeneity in the oceanic mantle is a subject of continuing debate (see, for example, White and Hofmann, 1982; Wood, 1979a; Schilling, 1973). One particular point of contention is whether the origin of the heterogeneity is related to a random distribution of distinct sources-the veined-mantle and/or plum-pudding models (Wood, 1979b; Davies, 1981) - or if the large part of the heterogeneity is related to the presence of mantle plumes (Schilling, 1975; White and Schilling, 1978).

The origin of the geochemical characteristics and their distribution in basalts erupted on the Mid-Atlantic Ridge (MAR) between 30 and $40^{\circ} \mathrm{N}$ has been explained by Schilling (1975) and White and Schilling (1978) as a result of mixing between an Azores mantle plume/blob (AMP/B) and a depleted low-velocity layer (DLVL). Briefly, the major features of their model can be summarized as follows: (1) presently, there is a major mantle plume centered at $39^{\circ} \mathrm{N}$ (the Azores mantle plume) and possibly a minor plume at $35^{\circ} \mathrm{N}$ (the Oceanographer mantle plume); (2) the plume source(s) are characterized by higher abundances of $\mathrm{K}, \mathrm{Ba}, \mathrm{Sr}, \mathrm{Cs}$, and light rare earth elements (LREE) and are enriched in the radiogenic Sr, Nd, and $\mathrm{Pb}$ isotopes (White et al., 1976; Hawkesworth et al.,

\footnotetext{
${ }^{1}$ Bougault, H., Cande, S. C., et al., Init. Repts, DSDP, 82: Washington (U.S. Govt. Printing Office).

2 Addresses: (Jenner, present address) Department of Earth Sciences, Memorial Univer. sity of Newfoundland, St. John's, Newfoundland A1B 3XS Canada; (Hertogen) Katholieke Universiteit, Leuven Celestijnenlaan $200 \mathrm{C}$, B3030 Heverlee, Belgium; (Sachtleben and Schmincke) Ruhruniversităt, D-4630 Bochum, Federal Republic of Germany.
}

1979; Sun, 1980); (3) mixing of the end-member sources depends on a number of factors, including spreading rate and plume flux (the rate of which can vary considerably and can also be episodic). In support of their model, White (1977) and White and Schilling (1978) have shown that, at least qualitatively, the distribution patterns of $\mathrm{Sr}$ isotopic composition, REE, and LIL (large ion lithophile) elements are consistent with a binary mixing model. The authors have also summarized supportive geophysical and morphologic features.

In addition to ascribing the origin of the zero-age geochemical features of MAR basalts to AMP/B-DLVL mixing, Schilling et al. (1977) have extended the model to include older basalts. Based on variations in $(\mathrm{La} /$ $\mathrm{Sm})_{\mathrm{N}}$ ratios in basalts from Site 335 (Leg 37, $16 \mathrm{Ma}$ ), Site 332 (Leg 37, $3 \mathrm{Ma}$ ) (both from Aumento, Melson, et al., 1977), and FAMOUS (zero-age) (Schilling et al., 1977) suggested that the contribution from the AMP/B increases from (approximately) $0 \%$ at Site 335 to $30 \%$ at Site 332 and to $45 \%$ at the FAMOUS site.

At least one aim of the Leg 82 program was to determine if the geochemistry of basalts erupted over the last $35 \mathrm{Ma}$ between 30 and $40^{\circ} \mathrm{N}$ is related to the presence of the Azores mantle plume. In order to evaluate the hypotheses of Schilling and his co-workers and to determine the origins of the heterogeneity in Leg 82 basalts, we have studied a number of basalts from Leg 82 , using a wide variety of analytical techniques and approaches (see Sachtleben et al., in preparation ${ }^{3}$; Hertogen et al.,

\footnotetext{
${ }^{3}$ Sachtleben, Th., Schmincke, H.-U., Hertogen, J., and Jenner, G. A., in preparation. Petrology and geochemistry of Leg 82 basalts.
} 
Table 1. Sr and Nd isotopic compositions of basalts from Leg 82.

\begin{tabular}{|c|c|c|c|c|c|c|c|c|c|c|c|}
\hline $\begin{array}{l}\text { Sample no. } \\
\text { Hole-Core-Section } \\
\text { Interval or depth } \\
\text { in section in } \mathrm{cm} \\
\text { (Piece no.) } \\
\text { Specimen type }\end{array}$ & $\begin{array}{c}1 \\
556-3 \cdot 2\end{array}$ & $\begin{array}{c}\text { 44-45 (le) } \\
\mathrm{GL}\end{array}$ & $556 \cdot-4 \cdot 2$ & $\begin{array}{c}72-74(5) \\
\text { GL. }\end{array}$ & $\begin{array}{c}27-29(2 b) \\
\text { WR }\end{array}$ & $\begin{array}{c}105-108 \text { (13) } \\
\text { WR }\end{array}$ & $\begin{array}{c}7 \\
558-27 \cdot 3 \\
\\
\begin{array}{c}69-72(7) \\
\text { WR }\end{array}\end{array}$ & $\begin{array}{c}8 \\
558-28-3 \\
\begin{array}{c}118-120(15) \\
\text { WR }\end{array}\end{array}$ & $\begin{array}{c}9 \\
558-30-2 \\
\begin{array}{c}78-82(7) \\
\text { WRL }\end{array}\end{array}$ & $\begin{array}{c}10 \\
558-31-2 \\
\\
\begin{array}{c}39-41(36) \\
G L\end{array}\end{array}$ & $\begin{array}{c}11 \\
558-32-1 \\
\begin{array}{l}123-125(8 b) \\
\text { WR }\end{array}\end{array}$ \\
\hline \multicolumn{12}{|l|}{ Ratio } \\
\hline${ }^{87} \mathrm{Sr} /{ }^{86} \mathrm{Sr}$ & $0.70315 \pm 2$ & & $\begin{array}{l}0.70284 \pm 3 \\
0.70280 \pm 3\end{array}$ & $0.70283=3$ & $0.70319=3$ & $0.70389 \pm 2$ & $0.70358=2$ & $0.70359=2$ & $0.70335=2$ & $0.70332=3$ & $0.70367 \pm 2$ \\
\hline${ }^{143} \mathrm{Nd} /{ }^{144} \mathrm{Nd}^{6}$ & $0.513126 \pm 16$ & $0.513118 \pm 15$ & $0.513087 \pm 21$ & $0.513139 \pm 15$ & $0.513142 \pm 20$ & $0.513016=18$ & $0.512981=18$ & $0.513006 \pm 20$ & $0.512947 \pm 22$ & $0.512936 \pm 14$ & $0.512921 \pm 15$ \\
\hline $\begin{array}{l}{ }^{147} \mathrm{Sm} /{ }^{144} \mathrm{Nd}^{c} \\
{ }^{143} \mathrm{Nd} /{ }^{144}{ }_{\mathrm{Nd}}^{\mathrm{d}}\end{array}$ & $\begin{array}{l}0.222 \\
0.513075\end{array}$ & $\begin{array}{l}0.222 \\
0.513067\end{array}$ & $\begin{array}{l}0.222 \\
0.513036\end{array}$ & $\begin{array}{l}0.224 \\
0.513088\end{array}$ & $\begin{array}{l}0.228 \\
0.513090\end{array}$ & $\begin{array}{l}0.151 \\
0.512998\end{array}$ & $\begin{array}{l}0.177 \\
0.512940\end{array}$ & $\begin{array}{l}0.207 \\
0.512959\end{array}$ & $\begin{array}{l}0.157 \\
0.512911\end{array}$ & $\begin{array}{l}0.157 \\
0.512900\end{array}$ & $\begin{array}{l}0.150 \\
0.512887\end{array}$ \\
\hline
\end{tabular}

this volume; Dupré et al., this volume). In this paper, we report $\mathrm{Sr}$ and $\mathrm{Nd}$ isotopic compositions on 23 samples and REE abundances in 10 samples. The samples were selected to represent the spatial and temporal, as well as geochemical, characteristics of Leg 82 basalts. Discussion of the data is broadly divided into two sections: one concerned with in-site variation, and the second concerned with how the data can be useful in delineating the origin of the heterogeneity.

The correlations between trace, $\mathrm{Sr}$, and $\mathrm{Nd}$ isotopic composition and $\mathrm{Pb}$ isotopic composition are also briefly discussed. This aspect of the paper comes from joint work with B. Dupré at Mainz, in which 10 samples were analyzed for $\mathrm{Sr}, \mathrm{Nd}$, and $\mathrm{Pb}$ isotopic composition and REE abundances. For a more complete discussion of $\mathrm{Pb}$ techniques and results, see Dupré et al. (this volume).

\section{METHODS}

Conventional chemical techniques were used for the separation of Sr, Nd, and REE (see White and Patchett [1984] for details). Details of the blanks and mass spectrometry are also given in White and Patchett (1984). In this study, more specifically measured blanks are Sm $<50 \mathrm{pg} ; \mathrm{Nd}<180 \mathrm{pg}$; and $\mathrm{Sr}<200 \mathrm{pg}$. Nd isotopic compositions were determined using double-filament, single-collector, and conventional-massspectrometric methods. $\mathrm{Sr}$ isotopic compositions were determined using a double-collector system installed on a Finnigan MAT 261 mass spectrometer. Errors reported for isotopic composition (Table 1) are two standard errors of the mean based on within-run statistics. This statistic slightly underestimates reproducibility.

The 10 samples for which REE data are reported (Table 2) were also analyzed for $\mathrm{Pb}$ isotopic composition. The procedure used for dissolution of these samples differed from that used on the other 13 samples. In particular, these samples had a 1-hour leach in warm $6 \mathrm{~N} \mathrm{HCl}$, followed by $\mathrm{Pb}$ separation. The residue after $\mathrm{Pb}$ extraction was treated with $\mathrm{HClO}_{4}, \mathrm{HF}, \mathrm{HCl}$, and the solution was split for isotope dilution (REE) and isotope composition analysis.

\section{RESULTS}

$\mathrm{Sr}$ and $\mathrm{Nd}$ isotopic compositions are reported in Table 1. Nd isotopic compositions have been corrected for age using the criteria given in Table $1 . \mathrm{Sm} / \mathrm{Nd}$ ratios for samples $2,3,4,9,10,12,13,17,18$, and 23 (see Table 1 for DSDP designations) are based on the isotope dilution REE measurements reported in Table 2; those for other samples are from the instrumental neutron activation data reported by Hertogen et al. (this volume). Values for CHUR (chondritic uniform reservoir) used in the $\epsilon \mathrm{Nd}_{(\mathrm{T})}$ calculations are based on a present-day value for $\left({ }^{143} \mathrm{Nd} /{ }^{144} \mathrm{Nd}\right)_{\mathrm{CHUR}}=0.51264$ and $\left({ }^{147} \mathrm{Sm} /{ }^{144} \mathrm{Nd}\right)_{\mathrm{CHUR}}$ $=0.1966$. A summary of important trace element and isotopic data is given in Table 3. Chemical groups given in Table 3 refer to those assigned by the shipboard scientists. These groups do not conform to the subdivision into N (normal)-MORB and E (enriched)-MORB often used. For the purposes of this paper, N-MORB has Hf/ $\mathrm{Ta}>7, \mathrm{Zr} / \mathrm{Nb}>13$, and $(\mathrm{Ce} / \mathrm{Sm})_{\mathrm{N}}<1$; E-MORB has $\mathrm{Hf} / \mathrm{Ta}<7, \mathrm{Zr} / \mathrm{Nb}<13$, and $(\mathrm{Ce} / \mathrm{Sm})_{\mathrm{N}}>1$. This nomenclature is similar to that used by Wood et al. (1979), Sun et al. (1979), and many others.

Hole 556. All the samples analyzed are N-MORB; however, they come from two different shipboard-designated chemical groups. Within the limits of analytical error, all these basalts may be considered to have come from a source that is approximately uniform isotopically (see Table 3 ). The variation in Nd isotopic composition $\left(\epsilon \mathrm{Nd}_{(\mathrm{T})}=8.6\right.$ to 9.7) may indicate some heterogeneity, but further study is necessary for confirmation.

Hole 557. Only one sample was analyzed for isotopic composition. This sample is an E-MORB with an $\epsilon$ $\mathrm{Nd}_{(\mathrm{T})}$ value of 7.4.

Hole 558. Eight samples were analyzed from this location. These basalts can show marked heterogeneity in trace and isotopic characteristics; however, the degree of correlation between the two types of heterogeneity is variable. The following points are notable: (1) Sample 8 (558-28-3, 118-120 cm), with N-MORB characteristics, compared to Sample 7 (558-27-3, 69-72 cm), an E-MORB, has essentially indistinguishable $\mathrm{Nd}($ and $\mathrm{Pb}$ ) isotopic composition; (2) Samples 8 and 13 (558-33-3, 133-136 cm) have N-MORB characteristics and identical Nd isotopic composition; however, they are different with respect to ${ }^{206} \mathrm{~Pb} / 204 \mathrm{~Pb}$ and ${ }^{208} \mathrm{~Pb} /{ }^{204} \mathrm{~Pb}$ composition; (3) Sample 8 versus Sample 12 (558-33-2, 22-25 cm) (N-MORB versus E-MORB) shows trace element heterogeneity accompanied by both $\mathrm{Nd}$ and $\mathrm{Pb}$ isotopic heterogeneity; (4) the ${ }^{143} \mathrm{Nd} /{ }^{144} \mathrm{Nd}$ isotopic compositions are positively correlated with ${ }^{147} \mathrm{Sm} /{ }^{144} \mathrm{Nd}$ (i.e., the data define an isochron/mixichron with an "age" of $224 \pm 51 \mathrm{Ma}$ ).

Hole 559. The single sample selected from this site is an E-MORB with $\epsilon \mathrm{Nd}_{(\mathrm{T})}$ of 7.5.

Hole 561. Four samples were selected; the uppermost one is an E-MORB with $\epsilon \mathrm{Nd}_{(\mathrm{T})}$ of 6.9 , whereas the other samples are N-MORB with $\epsilon \mathrm{Nd}_{(\mathrm{T})} \sim 9$. In compari- 
Table 1. (Continued).

\begin{tabular}{|c|c|c|c|c|c|c|c|c|c|c|c|}
\hline $\begin{array}{c}12 \\
558.33 \cdot 2\end{array}$ & $\begin{array}{c}13 \\
558-33-3\end{array}$ & $\begin{array}{c}14 \\
558-40-1\end{array}$ & $\begin{array}{c}15 \\
559-8-1\end{array}$ & $\stackrel{16}{16}$ & $\stackrel{17}{561-1 \cdot 1}$ & $\begin{array}{c}18 \\
56 !-I-2\end{array}$ & $\begin{array}{c}19 \\
561 \cdot 3 \cdot 2\end{array}$ & $\begin{array}{c}20 \\
562-8.2\end{array}$ & $\begin{array}{c}21 \\
563-25-1\end{array}$ & $\stackrel{22}{564-1 \cdot 2}$ & $\begin{array}{c}23 \\
564-2-2\end{array}$ \\
\hline $\begin{array}{c}22-25(29) \\
G L\end{array}$ & $\begin{array}{l}133-136(3) \\
\text { WRL }\end{array}$ & $\begin{array}{c}92-94(8 a) \\
\text { WR }\end{array}$ & $\begin{array}{c}127-129(5 c) \\
\text { WR }\end{array}$ & $\begin{array}{c}\text { 33-38 (2a) } \\
\text { WR }\end{array}$ & $\begin{array}{l}128-133 \\
\text { WRL }\end{array}$ & $\begin{array}{l}19-21 \\
\text { WRL }\end{array}$ & $\begin{array}{l}41-53(3 c) \\
\text { WR }\end{array}$ & $\begin{array}{c}6-9(1) \\
\text { WR }\end{array}$ & $\begin{array}{c}19-22(1 c) \\
\text { WR }\end{array}$ & $\begin{array}{c}21-25 \text { (3a) } \\
\text { WR }\end{array}$ & $\begin{array}{c}90-92 \text { (Sc) } \\
\text { GL }\end{array}$ \\
\hline $0.70333 \pm 2$ & $0.70334 \pm 2$ & $\begin{array}{l}0.70399 \pm 2 \\
0.70395 \pm 3\end{array}$ & $0.70331 \pm 2$ & $0.70394=2$ & $0.70319 \pm 3$ & $0.70293 \pm 2$ & $0.70398 \pm 2$ & $0.70355=2$ & $0.70307=3$ & $0.70227 \pm 2$ & $0.70254 \pm 3$ \\
\hline $0.512942 \pm 23$ & $0.513000=21$ & $0.512974 \pm 16$ & $0.513018 \neq 15$ & $0.512988 \pm 21$ & $0.513094 \pm 21$ & $0.513120 \pm 25$ & $0.513096 \pm 20$ & $\begin{array}{l}0.513145 \pm 36 \\
0.513143 \pm 17\end{array}$ & $0.513227 \pm 17$ & $0.513199 \pm 32$ & $0.513184 \pm 15$ \\
\hline 0.157 & 0.194 & 0.190 & 0.176 & 0.153 & 0.268 & 0.276 & 0.230 & 0.213 & 0.236 & 0.232 & 0.216 \\
\hline 0.512906 & 0.512956 & 0.512931 & 0.512978 & 0.512971 & 0.513064 & 0.513089 & 0.513070 & 0.513118 & 0.513173 & 0.513146 & 0.513135 \\
\hline
\end{tabular}

Table 2. Isotope dilution, rare earth element abundances (in ppm).

\begin{tabular}{lcrrrrrrrrr}
\hline $\begin{array}{l}\text { Sample } \\
\text { number } \\
\text { Hole }\end{array}$ & 2 & 5 & 4 & 9 & 10 & 12 & 13 & 17 & 18 & 23 \\
\hline Element & 556 & 556 & 556 & 558 & 558 & 558 & 558 & 561 & 561 & 564 \\
\hline $\mathrm{Ce}$ & 6.62 & 7.13 & 6.90 & 23.00 & 22.90 & 18.70 & 7.45 & 3.33 & 3.25 & 8.70 \\
$\mathrm{Nd}$ & 6.62 & 7.18 & 6.98 & 13.60 & 13.60 & 11.10 & 5.98 & 4.10 & 4.40 & 7.87 \\
$\mathrm{Sm}$ & 2.42 & 2.63 & 2.58 & 3.53 & 3.51 & 2.86 & 1.92 & 1.81 & 2.00 & 2.80 \\
$\mathrm{Eu}$ & 0.86 & 0.94 & 0.94 & 1.21 & 1.20 & 1.00 & 0.94 & 0.85 & 0.94 & 1.04 \\
$\mathrm{Gd}$ & & 3.74 & 3.69 & 4.00 & 3.98 & 2.91 & 2.57 & 2.92 & 3.28 & 3.84 \\
$\mathrm{Dy}$ & 4.26 & 4.61 & 4.54 & 4.52 & 4.47 & 3.55 & 2.91 & 3.88 & 4.27 & 5.00 \\
$\mathrm{Er}$ & 2.76 & 2.98 & 2.93 & 2.76 & 2.75 & 2.25 & 1.73 & 2.53 & 2.80 & 3.18 \\
$\mathrm{Yb}$ & 2.59 & 2.81 & 2.76 & 2.53 & 2.53 & 2.05 & 1.59 & 2.45 & 2.68 & 3.07 \\
$\mathrm{Lu}$ & 0.36 & 0.41 & 0.40 & 0.37 & 0.37 & 0.30 & 0.23 & 0.37 & 0.40 & \\
\hline
\end{tabular}

Note: For DSDP designations of sample numbers, see Table 1. Errors are approximately 2-3\% for $\mathrm{Ce}, \mathrm{Nd}, \mathrm{Sm}, \mathrm{Eu}, \mathrm{Er}, \mathrm{Yb}$, and $\mathrm{Lu}$, and $4-6 \%$ for $\mathrm{Gd}$ and $\mathrm{Dy}$.

son to Hole 558 basalts, the change in isotope characteristics between E-MORB and N-MORB are much more notable.

Holes 562, 563, and 564. All of the basalts analyzed are N-MORB. The initial ${ }^{143} \mathrm{Nd} /{ }^{144} \mathrm{Nd}$ ratios are generally higher than those for the other N-MORB samples studied here, but they are more consistent with those suggested as characterizing the N-MORB source region (White and Hofmann, 1982).

\section{DISCUSSION}

\section{Isotopic Variability}

Figure 1 shows the variation in the $\mathrm{Nd}$ and $\mathrm{Sr}$ isotopic composition of Leg 82 basalts. The results include data from fresh glasses, leached whole rocks, and whole rocks. Almost all the samples are olivine-hypersthene normative tholeiites and were selected as among the freshest samples available. No leached-unleached whole-rock pairs were tested; however, it appears that at least seven of the whole rocks have undergone significant alteration in $\mathrm{Sr}$ isotopic composition because of seawater/basalt interaction. Because of the uncertainty involved in using the whole-rock ${ }^{87} \mathrm{Sr} /{ }^{86} \mathrm{Sr}$ ratios, only ${ }^{87} \mathrm{Sr} /{ }^{86} \mathrm{Sr}$ data from the glasses and leached whole rocks are used to describe source characteristics.

The range of variation observed in $\mathrm{Nd}$ and $\mathrm{Sr}$ isotopic composition in Leg 82 basalts is quite large (spanning $5 \epsilon \mathrm{Nd}$ units). The pattern shown is consistent with previous studies on MORB; however, although all Leg 82 basalts would be considered MORB, they overlap in composition with the Azores Islands basalts. It is also somewhat surprising that in spite of having N-MORB with depleted to very depleted trace element abundances and
Table 3. Shipboard chemical group; selected trace element and isotopic compositions for analyzed samples.

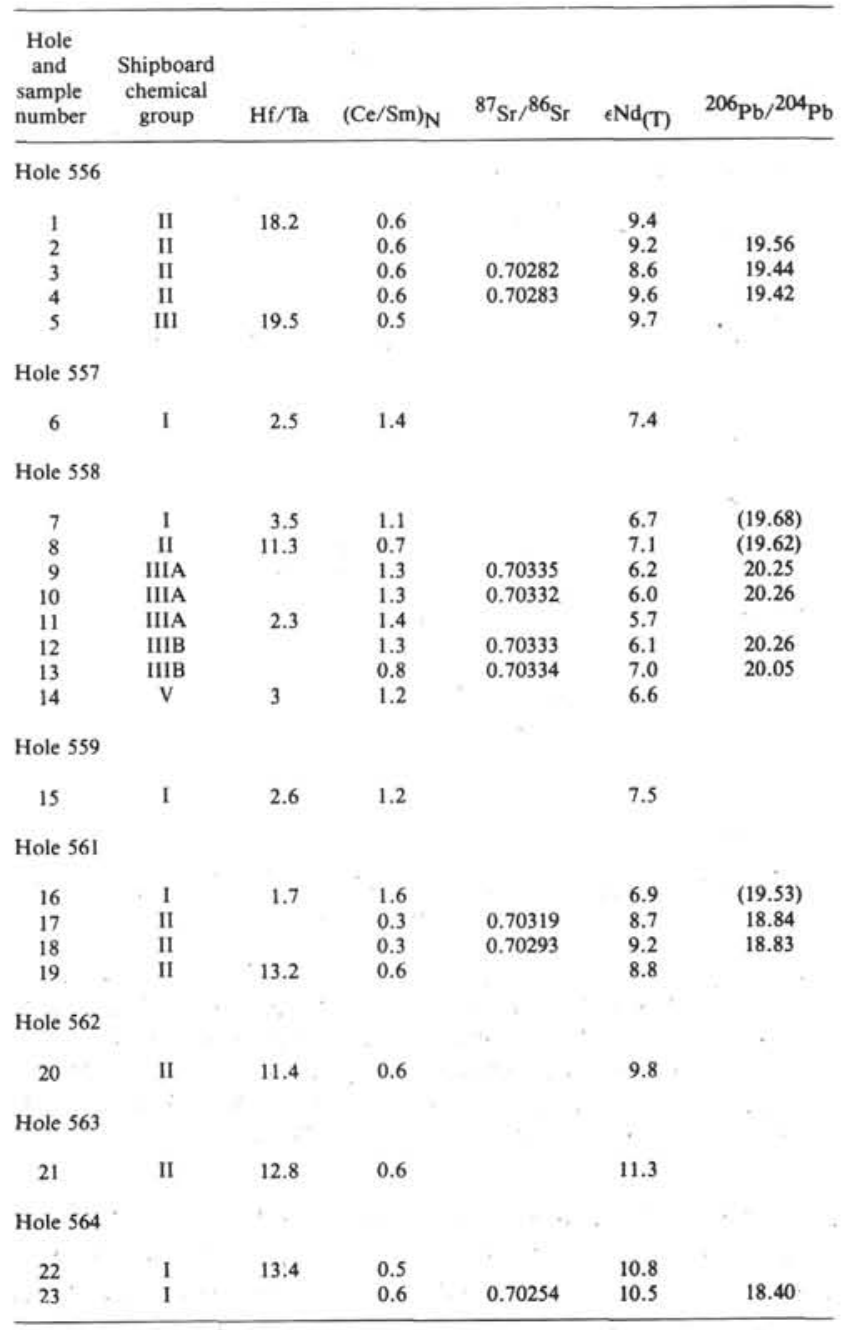

Note: For DSDP sample designations, see Table 1. Hf/Ta ratios from Hertogen et al. (this volume). $(\mathrm{Ce} / \mathrm{Sm})_{\mathrm{N}}$ values are normalized to chondritic abundances. ${ }^{87} \mathrm{Sr} /$
$86 \mathrm{Sr}$ ratios are for glasses or leached whole rocks. $206 \mathrm{~Pb} / 204 \mathrm{~Pb}$ values are from ${ }^{86} \mathrm{Sr}$ ratios are for glasses or leached whole rocks. $206 \mathrm{~Pb} / 204 \mathrm{~Pb}$ values are from
Dupré et al. (this volume). Values in parentheses indicate that the values are from the same unit, but not from the same sample.

patterns (see Hertogen et al., this volume), many of the N-MORB recovered during Leg 82 have initial ${ }^{143} \mathrm{Nd} /$ ${ }^{144} \mathrm{Nd}$ less than that of the mean N-MORB reservoir (taken to be 0.51315 for zero-age basalts) (Jenner et al., in press).

Variation in ${ }^{87} \mathrm{Sr} /{ }^{86} \mathrm{Sr}$ is correlated with ${ }^{206} \mathrm{~Pb} /{ }^{204} \mathrm{~Pb}$ (Fig. 2) in a similar manner as observed in other MORB. 


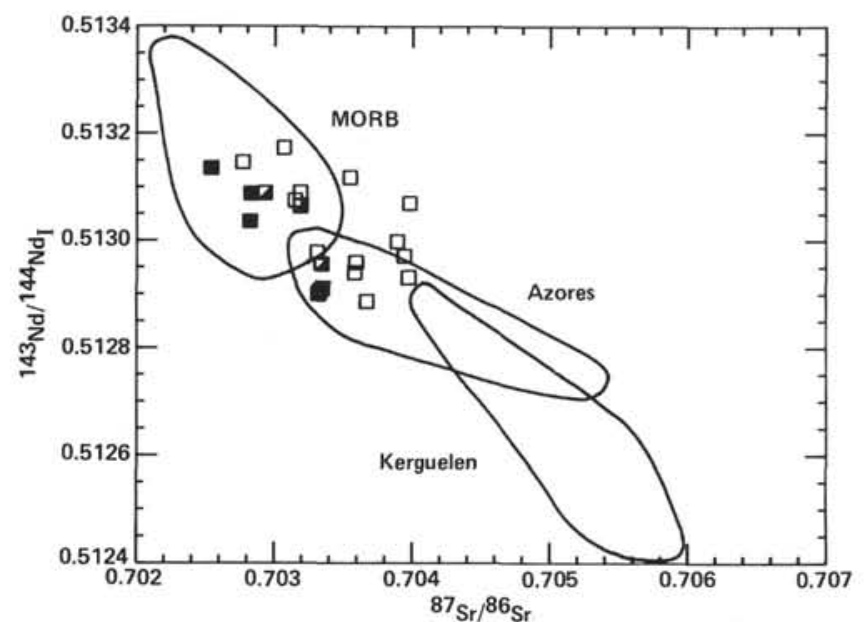

Figure 1. Initial ${ }^{143} \mathrm{Nd} /{ }^{144} \mathrm{Nd}$ versus ${ }^{87} \mathrm{Sr} /{ }^{86} \mathrm{Sr}$ for Leg 82 basalts. Solid squares $=$ glasses; half-filled squares $=$ leached whole-rock samples; open squares $=$ whole-rock powders (no leach). Comparison fields from published literature and unpublished data from MaxPlanck-Institute. MORB $=$ Mid-ocean ridge basalts.

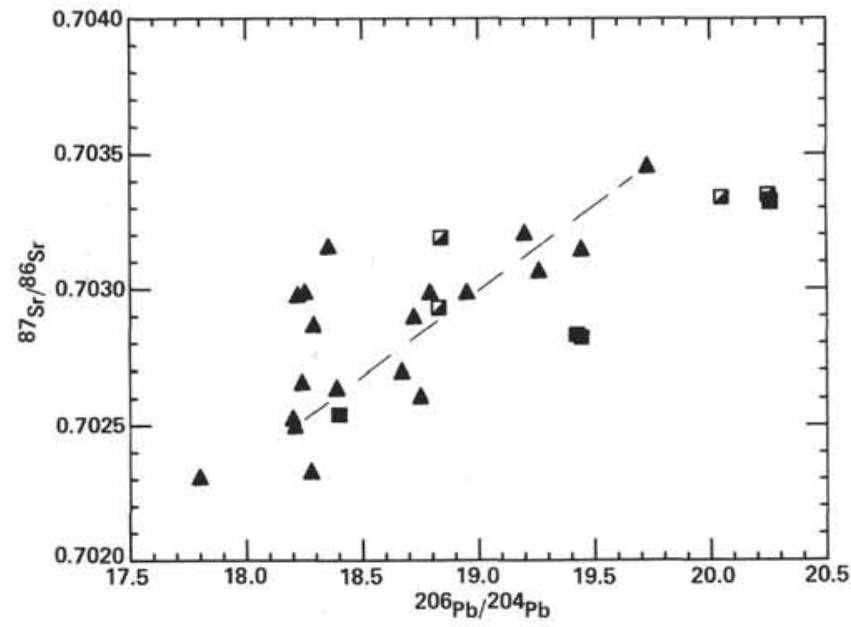

Figure 2. Comparison of ${ }^{87} \mathrm{Sr} /{ }^{86} \mathrm{Sr}$ versus ${ }^{206} \mathrm{~Pb} /{ }^{204} \mathrm{~Pb}$ for Leg 82 basalts and MORB. Triangles $=$ data from Cohen and O'Nions (1982) and Dupré and Allegre (1980); dashed line shows trend from MidAtlantic Ridge (MAR) basalts (zero age); solid squares = glasses, Leg 82 ; half-filled squares $=$ leached whole rocks. $(\mathrm{Pb}$ isotopic data for Leg 82 from Dupré et al., this volume.)

Note that the range of variation shown in Leg 82 is equivalent to, if not greater than, that previously observed in MORB. The dashed line in Figure 2 indicates the trend shown by MAR MORB. Compared to that MAR "trend," the Leg 82 basalts show some significant deviations at Sites 556 and 558. At these two sites, there is a markedly more radiogenic $\mathrm{Pb}$ isotopic composition for a given $\mathrm{Sr}$ isotopic composition. $\mathrm{Pb}$ isotopic composition in these sites is also anomalous with respect to the trace element characteristics of the sites (see Dupré et al., this volume).

\section{Trace Element and Isotope Tests for Binary Mixing}

As outlined in the introduction, Schilling and his coworkers (Schilling 1975, and White and Schilling, 1978) have developed a series of hypotheses relating variations in chemical characteristics to mixing between AMP/B and DLVL. As a first approximation, these authors have considered the mixing to be binary and also assumed that trace element ratios can be used to indicate the relative amount of components present. Accepting these conditions, one would hope to find a consistent (predictable) relationship between trace element and isotopic variation. To evaluate this possibility we have tested for mixing using trace elements and trace-element-isotope pairs. Because of our wider data base for initial Nd isotopic composition, only this isotopic system is considered here. Dupré et al. (this volume) discuss qualitatively the results for $\mathrm{Pb}$ isotopes versus trace elements.

Initial tests for a binary mixing relationship were made using variations in $\mathrm{La} / \mathrm{Ce}$ versus $\mathrm{Tb} / \mathrm{Yb}$. These elements and ratios were selected for the following reasons: (1) an extensive base of good data was available (see Hertogen et al., this volume); (2) both ratios were thought to be reasonably free of fractional crystallization effects and thus to reflect source characteristics; (3) the ratio pairs were sufficiently different so as to minimize the introduction of artificially good mixing fits given element similarities. The variation in $\mathrm{La} / \mathrm{Ce}$ versus $\mathrm{Tb} / \mathrm{Yb}$ is shown in Figure 3. The mixing curve illustrated was calculated for E-MORB and N-MORB samples analyzed by Hertogen et al. (this volume). The scatter about this curve is similar to that found in earlier studies by Schilling (1975) and White and Schilling (1978).

It is easier to evaluate the mixing hypothesis using the reciprocal plot (Langmuir et al., 1978) of $\mathrm{La} / \mathrm{Ce}$ versus $\mathrm{Yb} / \mathrm{Ce}$. In this plot a straight line should be formed with the data in the same relative order. For the data illustrated (Fig. 4), it is possible to calculate a linear leastsquares regression line with $\mathrm{r}^{2}=0.87$. This result essentially confirms the results of previous studies and would

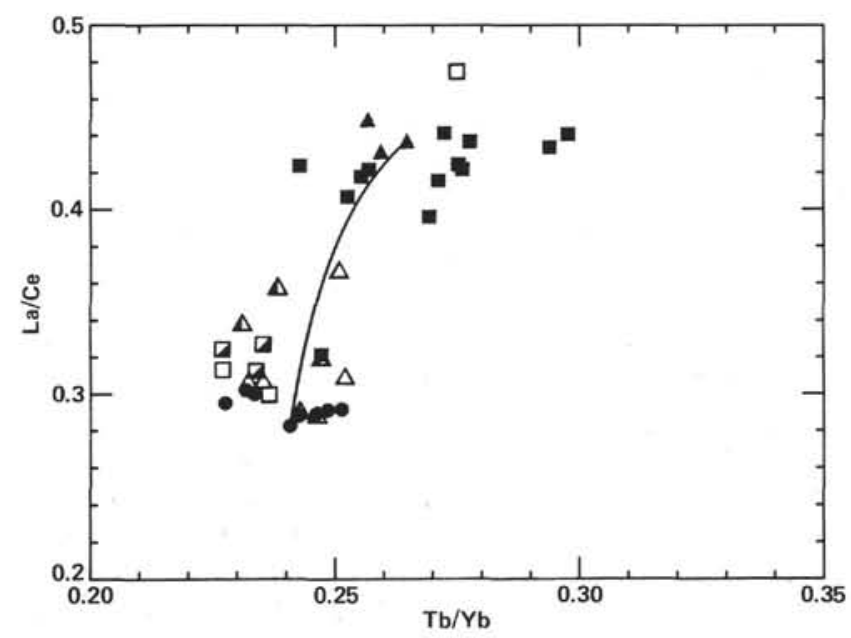

Figure 3. $\mathrm{La} / \mathrm{Ce}$ versus $\mathrm{Tb} / \mathrm{Yb}$ for Leg 82 basalts. Open symbols $=17$ Ma (Hole 558 = square; Hole $562=$ triangle). Closed symbols = $35 \mathrm{Ma}$ (Hole 556 = circles; Hole $558=$ square; Hole $559=$ triangle). Half-filled symbols = $35 \mathrm{Ma}$ (Hole $563=$ square; Hole 564 $=$ triangle). Solid line is calculated mixing curve between samples from Sections 556-2-5 and 559-8-1 (see Hertogen et al., this volume). 


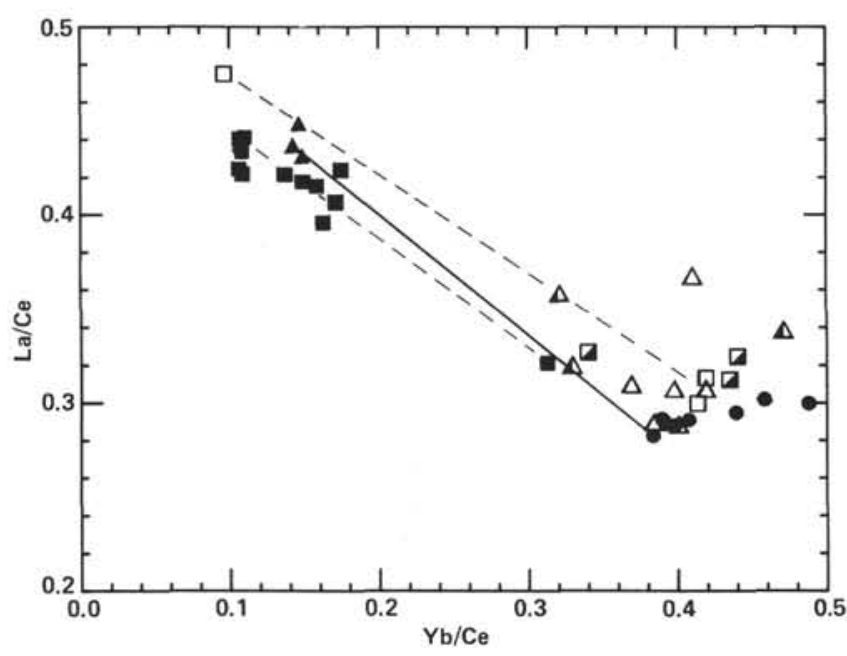

Figure 4. Reciprocal plot of $\mathrm{La} / \mathrm{Ce}$ versus $\mathrm{Yb} / \mathrm{Ce}$ for $\mathrm{Leg} 82$ basalts. Mixing line for samples from Sections 556-2-5 to 559-8-1 shown in solid line. Dashed lines are sketched-in possible mixing lines for variations observed at Sites 561 and 558. Symbols same as Figure 3.

model. However, it is informative to consider the data in more detail. Figure 4 shows a calculated mixing line for mixing between the same basalt pair used in Figure 3 . Also illustrated are two other possible mixing lines (note: dashed lines drawn between samples from same sites). It is possible then that the trends shown in Figures 3 and 4 illustrate mixing between different sets of binary endmembers.

The relationship between $\mathrm{Nd}$ isotopic composition and trace elements is illustrated in Figure 5. $\epsilon \mathrm{Nd}_{(\mathrm{T})}$ was chosen to illustrate the $\mathrm{Nd}$ isotopic variation so as to remove age differences, minimize effects caused by differential evolution of N-MORB and less-depleted reservoirs over the last $35 \mathrm{Ma}$, and facilitate easier discussion of the $\mathrm{Nd}$ isotopic composition. The $\mathrm{Ce} / \mathrm{Sm}$ ratio is used to illustrate the trace element variation because of the

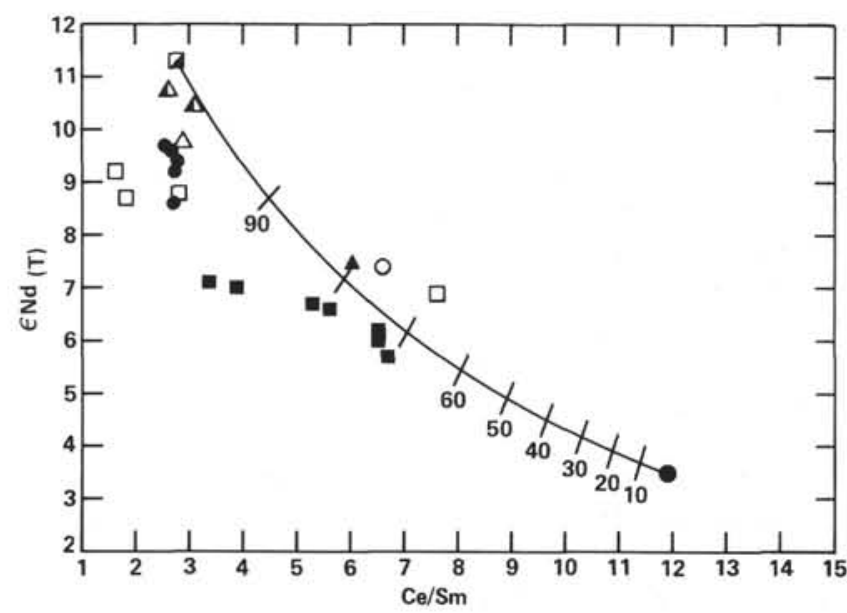

Figure 5. $\epsilon \mathrm{Nd}_{(\mathrm{T})}$ versus $\mathrm{Ce} / \mathrm{Sm}$ for Leg 82 basalts. Symbols same as Figure 3, except that the large solid circle = Faial 33 (Azores) and open circle $=$ Hole 557. Mixing curve is calculated for mixture of 563-25-1 and Faial 33. Labeled tick marks indicate percentage of N-MORB (563) end-member present. Trace and isotopic data for Faial 33 from White and Hofmann (1982) and White et al. (1979). poor trace element data base for the 10 samples jointly analyzed for $\mathrm{Pb}$ isotopic composition. The mixing curve shown was calculated for mixing between Samples 563-25-1 (an N-MORB from this study) and Faial 33 (an Azores Island basalt). Faial 33 was recommended by W. White, and if binary mixing is applicable, then it is a reasonable representation of the Azores Islands. However, this is not strictly true because isotopic heterogeneity in the Azores seems unlikely to be explained by simple binary mixing (Hawkesworth et al., 1979; Dupré et al., 1982; White, pers. comm., 1983).

In general, the correlation observed between $\epsilon \mathrm{Nd}_{(\mathrm{T})}$ and $\mathrm{Ce} / \mathrm{Sm}$ is the expected correlation for a mixing relationship between AMP/B and DLVL (i.e., E-MORB are characterized by lower $\epsilon \mathrm{Nd}_{(\mathrm{T})}$ values than N-MORB). The correlation is not as well developed as that required by a binary mixing model. Two points are worth noting (see also Table 3 and Fig. 5): (1) the basalts most depleted in trace element (Hole 556) do not have the highest $\epsilon \mathrm{Nd}_{(\mathrm{T})}$ values; and (2) in Hole 558 it is possible to find N-MORB and E-MORB with identical (within error) $\mathrm{Nd}$ isotopic compositions (see Results, Hole 558). As in the trace element mixing plots, it is easy to visualize a set of possible mixing curves as illustrated in Figure 5 .

To more carefully evaluate the relationship between $\mathrm{Nd}$ isotopic composition and trace element characteristics, and its significance for AMP/B-DLVL mixing, we have considered our data plus that from the literature for a possible mantle flow line between the FAMOUS site and Hole 558 (Leg 82). The Hole 558-FAMOUS flow line may be considered to be defined by or sampled by the following points: Hole 558 (Leg 82), $35 \mathrm{Ma}$; Hole 335 (Leg 37) $16 \mathrm{Ma}$; Hole 332 (Leg 37), $3 \mathrm{Ma}$; and FAMOUS, zero-age. Data sources are: this study; White, 1979; Schilling et al., 1977; Cohen and O'Nions, 1982; O'Nions et al., 1977.

Schilling et al. (1977) had suggested on the basis of REE data that the AMP/B contribution increased from $0 \%$ at Hole 335 to $30 \%$ at Hole 332 and to $45 \%$ in FAMOUS. Considered scatter was observed in the trace element characteristics at these sites (Schilling et al., 1977), but nonetheless a significant temporal variation seemed to exist. In contrast to the findings of Schilling et al. (1977), we would suggest the following (see Fig. 6):

1. Based on $\epsilon \mathrm{Nd}_{(\mathrm{T})}$, the plume component in Hole 335 , Hole 332, and the FAMOUS site can be considered to be constant at (for this specific model) $\sim 8 \%$.

2. REE data are not a good indication of plume component and give a range of $7-20 \%$ plume component.

3 . Hole 558 would have the highest plume component. Therefore, if this is due to an AMP/B influence, then there was a marked decrease in intensity between 35 and $16 \mathrm{Ma}$ followed by a relative constancy of plume effect. The effect on Hole 558 is greater than that at Hole 556 , although the latter would probably have been closer to the AMP/B source at $35 \mathrm{Ma}$.

4. Within Hole 558 there are basalts that appear to have trace elements and isotopic composition characteristics correlated, whereas others show marked trace element changes with no marked $\mathrm{Nd}$ isotopic variability. 


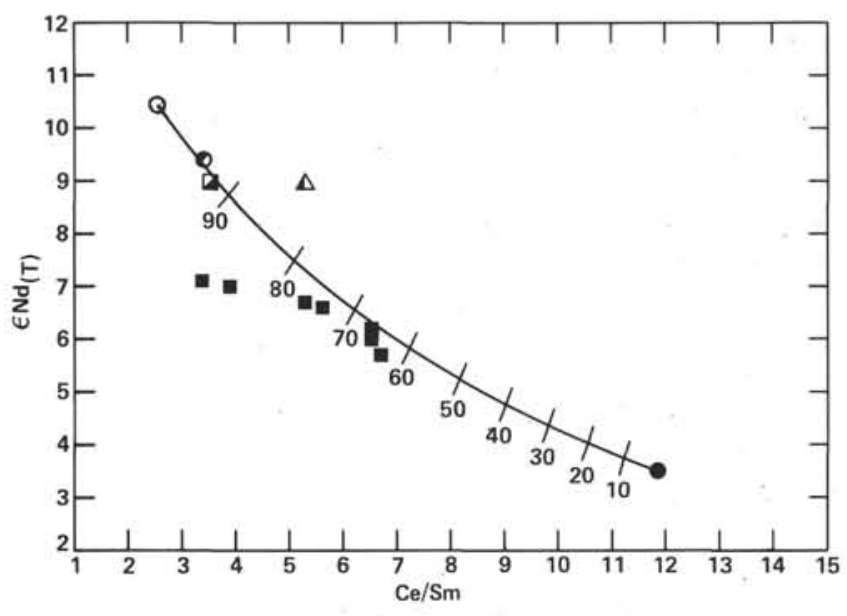

Figure 6. $\epsilon \mathrm{Nd}_{(\mathrm{T})}$ versus $\mathrm{Ce} / \mathrm{Sm}$ for possible Azores-Hole 558 flow line. Mixing line calculated for mixture of representative N-MORB reservoir basalt $\left(\epsilon \mathrm{Nd}_{(\mathrm{T})}=10.5\right.$ ) (large open circle) and Faial 33 (Azores) (large solid circle). Solid square $=$ Hole 558 samples; half-filled squares $=$ FAMOUS samples; half-filled triangle $=$ Site 332 samples; half-filled circle $=$ Site 335 samples .

\section{SUMMARY AND CONCLUSIONS}

The results presented here demonstrate that, in general, there is a correlation observed between isotopic and trace element characteristics in Leg 82 basalts. Those Leg 82 basalts classified as E-MORB have initial ${ }^{143} \mathrm{Nd} /$ ${ }^{144} \mathrm{Nd}$ ratios $<0.51300$, whereas, those basalts classified as N-MORB have initial ${ }^{143} \mathrm{Nd} /{ }^{144} \mathrm{Nd}$ ratios $>$ 0.51307 . A significant deviation from this general rule exists at Hole 558, where basalts defined as N-MORB by trace element characteristics have Nd isotopic characteristics of E-MORBs.

The degree of correlation observed between trace element and $\mathrm{Nd}$ isotopic composition is not as well developed as would be predicted by a unique binary AMP/BDLVL mixing model. Rather it seems likely that there are more localized sets of end-members involved in mixing relationships. It is also clear that trace elements alone are not a reliable indicator of the proportion of components in mixing relationships. This study confirms earlier results, based on work on Leg 37 samples and FAMOUS samples (cf., Blanchard et al. 1976; White, 1979; and Langmuir et al., 1977), that trace elements can be separated from isotopic characteristics and reflect complex processes occurring just before or during mixing/partial melting of the source.

The nature of the processes that lead to significant trace element fractionation without accompanying isotopic changes are not well defined. One possibility discussed for the FAMOUS basalts is the concept of dynamic melting; this model is discussed fully in the paper by Langmuir et al. (1977) and provides an explanation for variations in REE patterns where the samples retain similar ratios of $\mathrm{K} / \mathrm{Ba}, \mathrm{K} / \mathrm{Rb}, \mathrm{Rb} / \mathrm{Sr}$, and $\mathrm{Zr} / \mathrm{Nb}$. This model would not appear to explain the severe trace element fractionation seen in Hole 558, where the changes in REE pattern are also accompanied by significant fractionation of $\mathrm{Zr}(\mathrm{Hf})$ and $\mathrm{Nb}(\mathrm{Ta})$. With the presently avail- able limits on distribution coefficients for $\mathrm{Zr}$ and $\mathrm{Nb}$, it would appear that no plausible simple partial melting model can explain the variation observed in Hole 558 (cf., Le Roex et al., 1981). Veining of the mantle within $<200 \mathrm{Ma}$ before eruption of the Hole 558 basalts with a nephelinitic melt (cf., Wood, 1979b and Green, 1971) may be a partial solution, because mixes between these types of melts and DLVL sources can generate the right style of geochemical signature. The problem with Hole 558 is that it would appear to have had a reasonable chance of having E-MORB characteristics $\left(\epsilon \mathrm{Nd}_{(\mathrm{T})}=6\right.$ to 7), thus the problem is to generate the N-MORB characteristics. One possibility is that at some stage $(<200$ Ma before eruption) there was a local redistribution of elements caused by incipient partial melting, in which there was a volatile phase present in sufficient quantity to fractionate the trace elements in a more complex manner than that resulting from simple batch melting. In contrast to the "normal" veining episode, this melting/ veining episode must generate a depleted trace element signature on top of an enriched isotope signature. The $\mathrm{Pb}$ isotopic variation observed in Hole 558 basalts suggests a possible redistribution event involving a fluid phase (melt + volatiles). If this recent fluid had a high $\mu$ value $\left(\mu={ }^{238} \mathrm{U} /{ }^{204} \mathrm{~Pb}\right)$, it could help explain the relatively constant ${ }^{207} \mathrm{~Pb} /{ }^{204} \mathrm{~Pb}$ ratios and variable ${ }^{208} \mathrm{~Pb} /$ ${ }^{204} \mathrm{~Pb}$ and ${ }^{206} \mathrm{~Pb} /{ }^{204} \mathrm{~Pb}$ ratios observed in Hole 558 basalts (Dupré et al., this volume).

The observations that simple binary mixing is not strictly applicable to Leg 82 basalts, and that trace elements are not a reliable indicator of mixing components necessitate a revision of the hypotheses proposed by Schilling and his co-workers (Schilling, 1975; and White and Schilling, 1978). The distribution of the observed heterogeneities also do not fit any simple AMP/B-DLVL mixing model. If initial ${ }^{143} \mathrm{Nd} /{ }^{144} \mathrm{Nd}$ ratios $<0.51305$ are taken as evidence for a significant plume component in the source, then we would conclude that there was a plume input at the following: Sites 558 and 559 at $35 \mathrm{Ma}$; Sites 557 and 561 at $17 \mathrm{Ma}$; and the Azores at 0-10 Ma. The origin of this plume input at Sites 559 and 561 might be attributed to the Oceanographer plume of White and Schilling (1978). In fact, the data presented in this study may favor the plume explanation for the heterogeneity observed on the MAR in the vicinity of the Oceanographer Fracture Zone rather than the alternative explanations offered by these authors. However, the presence of a "plume" over the last $35 \mathrm{Ma}$ in this area can only be inferred on geochemical grounds and lacks supporting bathymetric evidence. The Azores mantle plume may be the explanation for the characteristic geochemical and isotopic character ("plume input") at Site 557. However, it is difficult to attribute the plume input at Site 558 to the Azores mantle plume, as noted earlier in this paper. It is certainly possible to come up with AMP/B-DLVL explanations for the data. The plume hypothesis has become quite flexible with disconnected blobs, fluctuating intensity, and possibly "plume heterogeneity." At this stage the plume model becomes untestable and potentially unique to one area. We prefer to consider a model in which localized heterogeneity of 
not necessarily confirm or disprove the binary mixing both recent (e.g., Wood, 1979b; Green, 1971) and longterm ( $\left.>10^{9} \mathrm{Ma}\right)$ origin (e.g. Davies, 1981) plays a role. This type of heterogeneity may be superimposed upon regional heterogeneity generated by "plume mixing."

Resolution of the relative roles to be played by longlived local heterogeneity, recent heterogeneity caused by complex partial melting, and regional plume-DLVL mixing is beyond the scope of this paper. We note only that the distribution and nature of the heterogeneities observed in the Azores area require a reevaluation of the hypotheses proposed by Schilling and his co-workers (Schilling, 1975; White and Schilling, 1978; Schilling et al., 1977).

\section{ACKNOWLEDGMENTS}

We are grateful N. T. Arndt, M. Flower, J. M. Rhodes, and W. M. White for their reviews. The first author also wishes to thank "Wild Bill" for his generous help in assisting with the computing, analytical, and scientific problems encountered during this study. We also appreciate the stimulating discussions with B. Dupré, C. Chauvel, and F. Albarede.

\section{REFERENCES}

Aumento, F., Melson, W., et al., 1977. Init. Repts. DSDP, 37: Washington (U.S. Govt. Printing Office).

Blanchard D. P., Rhodes, J. M., Dungan, M. A., Rodgers, K. V., Donaldson, C. H., Brannon, J. C., Jacobs, J. W., and Gibson, E. K., 1976. The chemistry and petrology of basalt from Leg 37 of the Deep Sea Drilling Project. J. Geophys. Res. 81:4231-4246.

Cohen, R. S., and O'Nions, R. K., 1982. The lead, neodymium and strontium isotopic structure of ocean ridge basalts. J. Petrol. 23: 299-324.

Davies, G. F., 1981. The earth's neodymium budget and structure and evolution of the mantle. Nature, 290:208-213.

Dupré, B., and Allegre, C. J., 1980. Pb-Sr-Nd isotopic correlation and the chemistry of the North Atlantic mantle. Nature, 286:17-22.

Dupré, B., Lambert, B., and Allegre, C. J., 1982. Isotopic variations within a single oceanic island: the Terceira case. Nature, 299: 620-622.

Green, D. H., 1971. Composition of basaltic magmas as indicators of conditions of origin: application to oceanic volcanism. Phil. Trans. R. Soc. London, Ser. A, 268:707-725.

Hawkesworth, C. J., Norry, M. J., Roddick, J. C., and Vollmer, R., 1979. ${ }^{143} \mathrm{Nd} /{ }^{144} \mathrm{Nd}$ and ${ }^{87} \mathrm{Sr} /{ }^{86} \mathrm{Sr}$ ratios from the Azores and their significance in LIL-element enriched mantle. Nature, 280:28-31.

Jenner, G. A., Dupré, B., Goepel, C., and Hertogen, J., in press. Trace, rare earth and radiogenic isotope composition of Leg 82 basalts: constraints on processes affecting the composition of oceanic crust. J. Geodynamics.

Langmuir, C. H., Bender, J. F., Bence, A. E., Hanson, G. N., and Taylor, S. R., 1977. Petrogenesis of basalts from the FAMOUS area: Mid-Atlantic Ridge. Earth Planet. Sci. Lett., 36:133-156.

Langmuir, C. H., Vocke, R. D., and Hanson, G. N., 1978. A general mixing equation: applied to the petrogenesis of basalts from Iceland and the Reykjanes Ridge. Earth Planet. Sci. Lett., 37:380-392.
Le Roex, A. P, Erlank, A. J., and Needham, H. D., 1981. Geochemi$\mathrm{cal}$ and mineralogical evidence for the occurrence of at least three distinct magma types in the "FAMOUS" region. Contrib. Mineral. Petrol., 77:24-37.

O'Nions, R. K., Hamilton, P. J., and Evenson, N. M., 1977. Variations in ${ }^{143} \mathrm{Nd} /{ }^{144} \mathrm{Nd}$ and ${ }^{87} \mathrm{Sr} /{ }^{86} \mathrm{Sr}$ ratios in oceanic basalts. Earth Planet. Sci. Lett., 34:13-22.

Schilling, J.-G., 1973. Iceland mantle plume: geochemical study of Reykjanes Ridge. Nature, 242:565-571.

1975. Azores mantle blob: rare earth evidence. Earth Planet. Sci. Lett., 25:103-115.

Schilling, J.-G., Kingsley, R., and Bergeron, M., 1977. Rare earth abundances in DSDP Sites 332, 334, and 335, and inferences on the Azores Mantle Blob activity with time. In Aumento, F., Melson, W. G., et al., Init. Repts. DSDP, 37: Washington (U.S. Govt. Printing Office), 591-597.

Sun, S. S., 1980. Lead isotopic study of young volcanic rocks from mid-ocean ridges, ocean islands and island arcs. Phil. Trans. $R$. Soc. London, Ser. A, 297:409-445.

Sun, S. S., Nesbitt, R. W., and Sharaskin, A. Y., 1979. Geochemical characteristics of mid-ocean ridge basalts. Earth Planet. Sci. Lett., 44:119-138.

White, W. M., 1977. Geochemistry of igneous rocks from the Central North Atlantic: the Azores and the Mid-Atlantic Ridge [Ph.D. dissert.]. University of Rhode Island, Kingston.

, 1979. Geochemistry of basalts from the FAMOUS area: a reexamination. Carnegie Inst. Washington Year Book, 78:325-331.

White, W. M., and Hofmann, A. W., 1982. Sr and Nd isotope geochemistry of oceanic basalts and mantle evolution. Nature, 296: 821-825.

White, W. M., and Patchett, J., 1984. Hf-Nd-Sr isotopes and incompatible element abundances in island arcs: implications for magma origins and crust-mantle evolution. Earth Planet. Sci. Lett., 67: 167-185.

White, W. M., and Schilling, J.-G., 1978. The nature and origin of geochemical variation in Mid-Atlantic Ridge basalts from the Central North Atlantic. Geochim. Cosmochim. Acta, 42: 1501-1516.

White, W. M., Schilling, J.-G., and Hart, S. R., 1976. Evidence for the Azores mantle plume from strontium isotope geochemistry of Central North Atlantic. Nature, 263:659-663.

White, W., Tapia, M. D. M., and Schilling, J.-G., 1979. The petrology and geochemistry of the Azores Islands. Contrib. Mineral. Petrol., 69:201-213.

Wood, D. A., 1979a. Dynamic partial melting: its application to the petrogenesis of basalts erupted in Iceland, the Faeroe Islands, the Isle of Skye (Scotland) and the Troodos Massif (Cyprus). Geochim. Cosmochim. Acta, 43:1031-1046.

1979b. A variably veined suboceanic upper mantle-genetic significance for mid-ocean ridge basalts from geochemical evidence. Geology, 7:499-503.

Wood, D. A., Joron, J. L., and Treuil, M., 1979. A re-appraisal of the use of trace elements to classify and discriminate between magma series erupted in different tectonic settings. Earth Planet. Sci. Lett., $45: 326-336$

Date of Initial Receipt: 21 April 1983

Date of Acceptance: 28 November 1983 